\title{
'I KNOW WHAT I DID IS WRONG, BUT...': INVESTIGATING THE FACTORS OF STUDENTS' MORAL REASONING (ABSENTEEISM)
}

\author{
Aurelius Ratu, Ni Gusti Made Rai, dan Eka Dian Savitri \\ Sepuluh Nopember Institute of Technology Surabaya \\ email: aurelius.ratu@ts.ac.id
}

\begin{abstract}
This study wants to explore and examine the relationship between potential factors and the student's moral reasoning. Reasoning on moral decisions occurred when students should make a judgment of pursuing their academic goals. Several studies have tried to explain this from various perspectives. Every student was taken for granted to understand his ethical decisions in the academic process. However, the understanding showed that moral awareness has not correlated with the academic score (GPA) and gender variable. This research used quantitative method. The participants in this research were 521 students from 29 departments. The moral reasoning scale was measured by construct validity. Covariate analysis was used to generate a multivariable model. Based on the neutralization theory, the research found that the tendency to make justifications on immoral behaviour is higher for male students and is significantly done by the students at the GPA's level ranging from 2.01 to 2.5 . The characteroriented learning process is essential to help students in developing their moral awareness. Lack of understanding of how moral decisions to be made indicates a gap in the academic process which is dominated cognitive aspect. Imposing sanctions without character training does not provide a solution to problems that appear to be a small issue in education but can have a significant detrimental impact when the student immerses and works in society.
\end{abstract}

Keywords: socio-demographics, moral reasoning, education, students

$$
\begin{aligned}
& \text { ‘SAYA TAHU APA YANG SAYA LAKUKAN ITU SALAH, TETAPI...': } \\
& \text { INVESTIGASI FAKTOR-FAKTOR PENALARAN MORAL MAHASISWA (ABSENSI) }
\end{aligned}
$$

Abstrak: Penelitian ini bertujuan mengeksplorasi dan menguji hubungan antara faktor-faktor potensial dan penalaran moral siswa. Penalaran keputusan moral terjadi ketika siswa harus membuat keputusan untuk mengejar tujuan akademis mereka. Beberapa penelitian telah mencoba menjelaskan hal ini dari berbagai sudut pandang. Setiap siswa dianggap biasa untuk memahami keputusan etisnya dalam proses akademik. Namun, pemahaman tersebut menunjukkan bahwa kesadaran moral tidak berhubungan dengan variabel nilai akademik (IPK) dan jenis kelamin. Penelitian ini menggunakan metode kuantitatif. Partisipan dalam penelitian ini adalah 521 mahasiswa dari 29 jurusan. Skala penalaran moral diukur dengan validitas konstruk. Analisis kovariat digunakan untuk menghasilkan model multivariabel. Berdasarkan teori netralisasi, penelitian menemukan bahwa kecenderungan pembenaran atas perilaku asusila lebih tinggi pada mahasiswa laki-laki dan secara signifikan dilakukan oleh mahasiswa pada level IPK berkisar antara 2,01 sampai 2,5. Proses pembelajaran yang berorientasi pada karakter sangat penting untuk membantu mahasiswa dalam mengembangkan kesadaran moralnya. Kurangnya pemahaman tentang bagaimana keputusan moral akan diambil mengindikasikan adanya kesenjangan dalam proses akademik yang didominasi aspek kognitif. Pemberlakuan sanksi tanpa pelatihan karakter tidak memberikan solusi atas masalah yang tampaknya menjadi masalah kecil dalam pendidikan tetapi dapat memiliki dampak merugikan yang signifikan ketika mahasiswa membenamkan diri dan bekerja di masyarakat.

Kata Kunci: sosio-demografi, penalaran moral, pendidikan, mahasiswa

\section{INTRODUCTION}

Students' moral reasoning has been the subject of numerous studies. Most of them have examined this topic within the scope of academic behavior. In the educational environment, immoral behavior such as cheating or plagiarism arises because students 'quality' is only understood and 
placed on cognitive processes (Cartwright \& Menezes, 2014; Yaniv, Siniver, \& Tobol, 2017). There is a latent recognition that curriculum deals with cognitive aspects, while extra-curriculum deals with character development. On the other side, however, the quality of the graduates is understood from the perspective of the curriculum.

According to Bandura, proper function can be activated when someone deals with a dilemma that requires a moral decision (Bandura, 2002). Following this thesis, we observed that some researches had been done to get to a better understanding of this problem. One of these researches indicated that there is a correlation between a competitive system in an academic setting with cheating behavior (Anderman \& Midgley, 2004; Cartwright \& Menezes, 2014). Another research indicated that students with the highest grade point average had cheated or done plagiarism (Patall \& Leach, 2015). Some students even believed that immoral behaviour is essential to advance careers (Lawson, 2004).

This phenomenon revealed the graduates had only been considered in terms of grade point level. They were even considered as a part of personal responsibilities and not social responsibilities (Chung, 2016; Hakimi, Hejazi, \& Lavasani, 2011). In our society, this tendency has an indirect impact on the appearance of corrupt behaviour. Such behaviour arises because of the inability to understand the social impact of the wrong deeds. Efforts to include character development in the form of anti-corruption education lessons have not shown satisfactory results. The main influence factor is that the moral aspect is put in the responsibility of each student's belief (Ariyati \& Hapsari, 2017; Izzah, 2019; Ariani \& Kajen, 2014; Sudarsana, 2018). An overemphasis on cognitive aspects in the education process at the same time ignores moral issues and calls for personal responsibility.

We argue that the more students were under pressure, the more they were able to make reasoning on moral judgements. 'Rationalization' or justification on immoral behaviours was most likely conducted because of excessive pressure on personal responsibilities. It indicates the relationship between specific circumstances and their moral principles (Palmer, 2005). In this paper, we explore and examine if there is a relationship between potential factors and the student's moral reasoning.

To examine the relationship between potential factors and students' moral reasoning, it is necessary to explain the theory of neutralization. This theory is a part of theory deviant behaviour. Neutralization theory states that a person knows that the action is morally objectively wrong. However, because of reasoning, that action seemed right. It means that a person tries to avoid responsibility and to decrease negative emphasis from oneself and the others. These attempts came out of doing something wrong morally.

This theory was the development of Kohlberg's hypothesis and was introduced firstly by Sykes and Matza who observed that there are the tendencies one's moral development through education and experience is not followed by the application of moral conduct in certain situations (Stephens, 2007; Sykes \& Matza, 1957). In other words, this neutralization lessons negative judgements made by oneself and the others for the behaviour. Commonly, the neutralization is also called justifications. It means that an action is viewed as deviant behaviour and serving as protecting the individual from self-blame and the blame of others after the act. 
The emphasis on moral aspects in this study, at least, leads to what becomes a moral standard in a curriculum and an extracurriculum setting. In other words, the academic rules presuppose moral understanding as being incorporated into legal law for the students. However, several factors, such as motivation to achieve a better GPA (Grade Point Everage), environmental, and friendship influences, cause the existing rules forceless. Some studies found this phenomenon as an inconsistency between academic attitude and moral behaviour (Cartwright \& Menezes, 2014; Hakimi et al., 2011; Iorga, Ciuhodaru, \& Romedea, 2013; Lawson, 2004; Turiel, 2015). One of these inconsistencies is the behaviour of the absentee who entrusts oneself's presence to the others for avoiding his/herself from the lack of absent percentage in class. The behaviour reveals how students understand their moral principles, but at the same time, they can neutralize those principles for some reason.

Absentee behaviour, trusting oneself's presence, basically is not only concerning how moral awareness is often examined in an academic setting. It also actually shows that this moral awareness is always concerning the goals of the college, which want to create qualified graduates. This phenomenon highlighted an understanding of how the students believe their moral standards and acts on it. Following neutralization theory, we put on the assumption that everyone is innately motivated to make sense of their world, particularly events that are harmful, unexpected, or not normative (Murdock \& Stephens, 2007).

So far, the researches on the relationship between moral reasoning and organization engagement or people's achievements were conducted due to a competitive setting as it occurred within economics or a business context. If there was such research in an educational setting, it was conducted because of seeing education as a competetive climate (Cartwright \& Menezes, 2014; Crittenden, Hanna, \& Peterson, 2009; Schwieren \& Weichselbaumer, 2010).

Related to this relationship, we see that it was because of the education system, which runs differently for each country (Dale, 2010). In the context of our research, our college education system has been separating the curriculum and extra-curriculum activities. Based on this 'classification,' the extra-curriculum activities become a forum for the development of students' interests and talents, organizational training, and the ability to work together in teams. It becomes a unit where the students want to learn and to be an active member of the organization they chose.

As we observed, however, some wrong moral understandings related to academic or curriculum processes were started from such activities in an extra-curriculum process. We predicted that rationalization of immoral acts and judgements was most strongly taught in this context, althoughitappeared eventually most clearly as immoral behaviour in an academic context. Some researches called it 'a cultural problem' wherein the influences and implications on cognition and motivation for achieving the academic goals were affected (Koul, 2012; Langa, 2013).

\section{METHOD \\ Measures}

For our purpose, we developed 'ethical questionnaire measures' which was found by Don Forsyth (Forsyth, O'Boyle, \& McDaniel, 2008) into 20 statements (see appendix). The twenty statements were related to absentee behaviour, trusting oneself's presence to their peers. These moral reasoning statements were assessed by a 5- 
point scale where students were asked to give their approval from strongly disagree (1) to strongly agree (5). All statements were acceptable at 0,82 Cronsbach's alpha for the validated scale.

Table 1. Frequency Statistic from the Total Score on Moral Reasoning $(N=$ 521)

\begin{tabular}{|c|c|c|}
\hline \multicolumn{2}{|l|}{ Mean } & 56.68 \\
\hline \multicolumn{2}{|l|}{ Median } & 57.00 \\
\hline \multicolumn{2}{|c|}{ Std. Deviation } & 9,659 \\
\hline \multicolumn{2}{|l|}{ Skewness } & -.088 \\
\hline \multicolumn{2}{|c|}{ Std. Error of Skewness } & .107 \\
\hline \multicolumn{2}{|l|}{ Kurtosis } & -.245 \\
\hline \multicolumn{2}{|c|}{ Std. Error of Kurtosis } & .214 \\
\hline \multirow[t]{3}{*}{ Percentiles } & 25 & 50.00 \\
\hline & 50 & 57.00 \\
\hline & 75 & 63.00 \\
\hline
\end{tabular}

The original 20-item moral reasoning, in this case, was meant to assess the student moral belief through the student self-report scale. This self-report scale then was categorized into quartiles, as shown in Table 1.

\section{Participants}

Five hundred twenty-one students from 29 departments were asked to fill in a self-report questionnaire. It was conducted during the regular period of the learning process. The data concerning levels of moral reasoning on socio-demographics are shown in Table 2.

Table 2. Contingency Table Showing Moral Reasoning Levels by Demographic Variables $(N=521)^{*}$

\begin{tabular}{c|c|cccc}
\hline & $\begin{array}{c}\text { Catego- } \\
\text { ry } \\
\text { Percen- } \\
\text { tile }\end{array}$ & Low & $\begin{array}{c}\text { Medi- } \\
\text { um }\end{array}$ & $\begin{array}{c}\text { High } \\
25-49 \%\end{array}$ & $\begin{array}{c}\text { Very } \\
\text { High } \\
74 \%\end{array}$ \\
\hline & & $\mathrm{N}$ & $\mathrm{N}$ & $\mathrm{N}$ & $\mathrm{N}$ \\
\hline Gender & Male & 50 & 54 & 86 & 99 \\
& Female & 71 & 55 & 63 & 43 \\
\hline Age & $18-20$ & 99 & 94 & 138 & 129 \\
& $21-23$ & 22 & 15 & 11 & 13 \\
\hline Achieve & No & 79 & 78 & 106 & 104 \\
ment & Yes & 42 & 31 & 43 & 38
\end{tabular}

\begin{tabular}{c|c|cccc}
\hline $\begin{array}{c}\text { Organi- } \\
\text { zation } \\
\begin{array}{c}\text { Engage- } \\
\text { ment }\end{array}\end{array}$ & No & 32 & 28 & 43 & 45 \\
\hline $\begin{array}{c}\text { Educa- } \\
\text { tion }\end{array}$ & $\begin{array}{c}\text { Bache- } \\
\text { lor }\end{array}$ & 54 & 62 & 89 & 89 \\
& Diploma & 67 & 47 & 60 & 53 \\
\hline GPA & $<2.00$ & 2 & 3 & 0 & 0 \\
& $2.01-2.5$ & 15 & 5 & 8 & 3 \\
& $2.51-3.00$ & 19 & 28 & 41 & 32 \\
& $3.01-3.50$ & 56 & 47 & 66 & 65 \\
& $>3.51$ & 29 & 26 & 34 & 42 \\
\hline
\end{tabular}

Note: * Number and percentages based on cases with valid responses

\section{Data Analysis}

The moral reasoning scale was measured by construct validity (Strauss \& Smith, 2009). Scores on moral reasoning scale were categorized into quartiles. The cross-tabulation was then performed to avoid multicollinearity in independent variables. After removing highly correlated variables, any remaining variables were included in multivariate analysis. Proportional odds ordinal logistic regression was used to examine the relationship between moral reasoning and socio-demographic variables.

Covariate analysis was used to generate a multivariable model. All predictor whose $p$-value $<0,2$ were included and selected as a candidate for the multivariate analysis. The significance was then evaluated at 0,05 alpha level. Any variables which were higher than 0,05 alpha level were removed from the model. If any remaining variable gave a change in a parameter estimate greater than $15-20 \%$ (changed predictor coefficients), it could indicate a confounder variable in the model. Finally, proportional odds assumptions were tested. All data were analyzed using SPSS v.20. 


\section{RESULTS AND DISCUSSION}

Results

The mean for moral reasoning was 56,68 (Std Dev.9,7 and Skewness -0,822). Table 2 described the examination of moral reasoning towards the independent variables.

After all data were collected, and the scalemeasurement wasconducted, as shown in Table 3, we proceeded with bivariate correlate analysis. Gender and level of education had a robust correlation with the students' moral reasoning ( $\mathrm{p}$-value $<0,01$ ). So, it was decided to exclude the level of education from the model as it was decided gender was more relevant for this study. The bivariate result showed that the odds of making rationalization on moral decisions were higher in male students $(\mathrm{OR}=1,98$ $\mathrm{CI}=95 \%)$. The students' GPA ranging 2,012,5 and 3,01-3,5 had significant statistic (pvalue $<0,05)$.

The result also showed greater odds of making rationalization on moral decisions was higher in the students with GPA level between 3,01-3,5 (OR = 0,87 CI = 95\%) compared to $2,01-2,5(\mathrm{OR}=0,3 \mathrm{CI}=95 \%)$. The age variable ranging from 18-20 showed greater odds compared to the students with age ranges between 21-23.

The bivariate result for the extracurriculum activities showed little evidence of relationship ( $p$-value $<0,05$ ) between moral reasoning variable and organizational engagement, achievements. If measured with significant value ( $p$-value $<0,2$ ), the students who had no achievements had higher odds of doing moral reasoning compared to students who had achievements.

The initial multivariable model showed that only the gender variable remained significant and was confounded by students' GPA level between 2,01-2,5, which was still significant. After adjustment, the odds of doing rationalization on moral decisions related to the students' GPA level was higher in the 2,01-2,5. Another GPA level and age could not demonstrate a significant relationship (with $\mathrm{p}$-value $<0,05$ ).

Tabel 3. Scale Measurement and Bivariate Correlate Analysis about Gender and GPA Level

\begin{tabular}{|c|c|c|c|c|c|c|}
\hline & & \multirow[t]{2}{*}{$\mathrm{N}$} & \multicolumn{2}{|c|}{$\begin{array}{l}\text { Unadjusted Odds Rasio } \\
\text { (Initial Model) }\end{array}$} & \multicolumn{2}{|c|}{$\begin{array}{l}\text { Adjusted Odds Rasio } \\
\text { (Final Model) }\end{array}$} \\
\hline & & & Odds Ratio & Sig & Odds Ratio & Sig \\
\hline \multirow[t]{2}{*}{ Gender } & Male & 289 & 1,982 & 0,000 & 2,02 & 0,000 \\
\hline & Female & 232 & $1,00^{a}$ & & $1,00^{\mathrm{a}}$ & \\
\hline \multirow[t]{5}{*}{ GPA } & $<2.00$ & 5 & 0,222 & 0,058 & 0,253 & 0,084 \\
\hline & $2.01-2.5$ & 31 & 0,301 & 0,001 & 0,301 & 0,001 \\
\hline & $2.51-3.00$ & 120 & 1,082 & 0,717 & 1,215 & 0,382 \\
\hline & $3.01-3.50$ & 234 & 0,870 & 0,464 & 0,973 & 0,888 \\
\hline & $>3.51$ & 131 & $1,00^{\mathrm{b}}$ & & $1,00^{\mathrm{b}}$ & \\
\hline \multirow[t]{2}{*}{ Age } & $18-20$ & 460 & 1,719 & 0,022 & & \\
\hline & $21-23$ & 61 & $1,00^{\mathrm{b}}$ & & & \\
\hline \multirow[t]{2}{*}{ Achievement } & No & 367 & 1,274 & 0,146 & & \\
\hline & Yes & 154 & $1,00^{c}$ & & & \\
\hline \multirow[t]{2}{*}{ Organization Engagement } & No & 148 & 1,166 & 0,362 & & \\
\hline & Yes & 373 & 1,00 & & & \\
\hline
\end{tabular}

Note: All data with Confidence Interval $=95 \%$,

$\mathrm{a}=$ p-value $<0,01$

$\mathrm{b}=\mathrm{p}$-value $<0,05$

$\mathrm{c}=\mathrm{p}$-value $<0,2$ 


\section{Discussion}

The examination of students' moral reasoning was only based on the students' absentee behaviour, not on cheating or plagiarism. This research identified the relationship between the students' absentee behaviour and gender, GPA variables as socio-demographic variables.

\section{Moral Reasoning and GPA}

The findings of the current study showed a lack of evidence for the relationship between students' absentee behaviour and their achievements, their engagement in organizational activities as the extracurriculum process. The tendencies to make justification for immoral behaviours when the students dealt with a moral dilemma in achieving academic goals confirmed our assumption that the more students were under pressure, the more they were able to make reasoning on moral judgements (Campbell, 2017). This finding, however, has not answered whether these dishonest practices were found in extra-curricular activities.

Through the theory of neutralization viewpoint, extra-curricular activities do not emphasize personal eminence. Meanwhile, reactions such as justification for immoral behaviour reflects the influence of an institutional emphasis on levels of achievement. In the name of 'higher standard of graduates,' the learning process seems meaningless if the students consciously ignore the efforts to get layers on understanding. In the framework of neutralization techniques developed by Sykes and Matza (Sykes \& Matza, 1957), the results of our study show the most definite tendency to do absenteeism with students with a GPA between 2.01-2.5 and followed by students with a GPA below 2.0.
The higher education policy, which sets the graduation threshold of a course at a GPA between 2.01-2.5, explains the inability and hesitation of students to determine priorities for the attendance of their lectures. There was a logical fallacy concerning the importance of each course they took. That one course means more important than another does not seem to be well understood. They saw themself as caught up in a dilemma that must be resolved, unfortunately, at the cost of violating the law. The justification for immoral behaviour is then an inability to cope with the various demands.

\section{Moral Reasoning and Gender}

Concerning gender, the result showed the relationship between students' absentee behaviour and gender factor. Male students were twice in doing rationalization on moral principles than female students. As an attitude or behaviour, women hold a more negative attitude towards academic dishonesty. Our result confirmed the previous result that women's moral feelings and their negative attitude from the academic dishonesty were lower than men's (Whitley, 2001).

Contrary to what we found, in competitive pressure, women were more likely to do moral reasoning (Schwieren \& Weichselbaumer, 2010). This finding gives a new perspective on the understanding of the relationship between gender and moral reasoning. Available national or international studies up to this date have not reported this relationship. The previous studies just discussed ethics and professionalism in the educational environment (Farahani \& Farahani, 2014; Iorga, Ciuhodaru, \& Romedea, 2013). We argue that women's reactions are caused by the paradigm of society, which tends to judge women as second-class 
citizens. This paradigm causes women to be less concerned with academic achievement (Maria, Quintarti, Maria, et al., 2018; Mudaris, 2009; Prantiasih, 2014).

Furthermore, although the odds of students whose GPA level in 2.01-2,5 was one-third of students whose GPA level bigger than 3.5 , it was statistically significant. We have little evidence to state that our findings confirmed the previous research result, i.e., higher achievers are bigger cheaters (Yaniv et al., 2017). This current study indicated that GPA factor was confounded by gender variable, and alternatively, GPA factor increased the effect of gender variable in making the justification for immoral behaviour. The finding related to gender confirmed that in dishonest behaviour, women tend to obey the rule than men (Ward \& Beck, 1990).

This research explained several results that should be discussed in an educational setting. First, that decisions regarding moral issues in the education environment seem to be influenced by an overemphasis on the factor of 'creating quality graduates.' This statement tends to be interpreted as 'an individual achievement' rather than cooperation between people or team-work whereas the need for the quality human resources in the professional career is not merely measured from the GPA alone (Cohen \& Morse, 2014; Tan, Naidu, \& Osman, 2018). Second, development programs related to character building are needed. If the educational institution is seen as the last defense in maintaining moral behavior, then it is appropriate that the formation of the moral character itself is included in the curriculum (Aybek, Çavdar, \& Özabacı, 2015; Chung, 2016; Jose, 2013).

Our study has some limitations. First, the use of self-report measures of latent variables poses problems that students may feel the need to provide socially desirable responses to questions about sensitive issues such as absentee behaviour. Second, the sample population for the current study is limited to the engineering students. Further investigations need to pay attention to the wide-ranging population of students in higher education; especially in recent years, there is a paradigm shift towards gender in our society. In our opinion, attention to behavioural and character issues for the world of work today becomes one of the priorities over cognitive aspects such as GPA.

\section{CONCLUSIONS}

A relationship was found between moral reasoning and gender, GPA level among students. Male students were found at a higher level of making the justification for immoral behavior than females. The students who had a GPA level between 2,012,5 also were found to be related to a higher level of doing the justification among other students' GPA levels. The findings add a new insight regarding the relationship between moral reasoning and gender GPA. It suggests that male students whose GPA level between 2,01-2,5 was more inclined to make justification for immoral behavior for achieving their academic goals. In a society where GPA becomes a reference for one's success, we suggest that education should reconsider a long-term character development program. Imposing sanctions without character training does not provide a solution to problems that appear to be a small issue in education but can have a significant detrimental impact when the student immerses and works in society.

\section{ACKNOWLEDGEMENT}

The authors would like to sincerely thank all those who have helped the 
research until the completion of this paper. In particular, thanks are conveyed to the head of the Editorial Board of the Jurnal Pendidikan Karakter who has published this paper in the current edition.

\section{REFERENCES}

Anderman, E.M., \& Midgley, C. (2004). Changes in self-reported academic cheating across the transition from middle school to high school. Contemporary Educational Psychology, 29(4), 499-517. DOI: https://doi.org/10.1016/j.cedpsych.2004.02.002.

Ariani, I.H.D. \& Kajen, A. (2014). Menumbuhkan pendidikan karakter anti korupsi melalui pembelajaran carilem. Seminar Nasional Pendidikan, Sains dan Teknologi Fakultas Matematika dan Ilmu Pengetahuan Alam Universitas Muhammadiyah Semarang, 170-176. Retrieved from file:// C:/Users/LENOVO/Downloads/3056-6210-1-SM.pdf.

Ariyati, T., \& Hapsari, M. I. (2017). Program parenting berkelanjutan TK Aisyiyah I, II, III. Jurnal Sains Dan Sosial Humaniora, 1(2), 125-135. Retrieved from http://jurnalnasional.ump.ac.id/inde x.php/JSSH/article/view/1843/1683.

Aybek, E.C., Çavdar, D., \& Özabacı, T.M.N. (2015). University students' moral judgment and emotional intelligence level: A model testing. Procedia - Social and Behavioral Sciences, 191(2 June), 27402746. DOI: https://doi.org/10.1016/j.sbspro.2015.04.666.

Bandura, A. (2002). Selective moral disengagement in the exercise of moral agency. Journal of Moral Education, 31(2), 101-119. DOI: https://doi.org/10.1080/0305724022014322.
Campbell, R. (2017). Learning from moral inconsistency. Cognition, 167(October), 46-57. DOI: https://doi.org/10.1016/j.cognition.2017.05.006.

Cartwright, E., \& Menezes, M. L. C. (2014). Cheating to win: Dishonesty and the intensity of competition. Economics Letters, 122(1), 55-58. DOI: https://doi.org/10.1016/j.econlet.2013.10.016.

Chung, K. (2016). Moral muteness of faculty in management education. The International Journal of Management Education, 14(3), 228-239. DOI: https://doi.org/10.1016/j.ijme.2016.05.003.

Cohen, T.R., \& Morse, L. (2014). Moral character: What it is and what it does. Research in Organizational Behavior, 34, 4361. DOI: https://doi.org/10.1016/j.riob.2014.08.003.

Crittenden, V.L., Hanna, R.C., \& Peterson, R.A. (2009). The cheating culture: A global societal phenomenon. Business Horizons, 52(4), 337-346. DOI: https:/ / doi.org/10.1016/j.bushor.2009.02.004.

Dale, R. (2010). Globalization and curriculum. In P. Peterson, E. Baker, \& B. B. T.-I. E. of E. (Third E. McGaw (Eds.) (pp. 312317). Oxford: Elsevier. DOI: https://doi.org/https:/ / doi.org/10.1016/B97 8-0-08-044894-7.00049-X.

Farahani, M.F., \& Farahani, F.F. (2014). The study on professional ethics components among faculty members in the engineering. Procedia - Social and Behavioral Sciences, 116(21 February), 20852089. DOI: https://doi.org/10.1016/j.sbspro.2014.01.524.

Forsyth, D.R., O'Boyle, E.H., \& McDaniel, M.A. (2008). East meets west: A meta- 
analytic investigation of cultural variations in idealism and relativism. Journal of Business Ethics, 83(4), 813-833. DOI: https://doi.org/10.1007/s10551-0089667-6.

Hakimi, S., Hejazi, E., \& Lavasani, M.G. (2011). The relationships between personality traits and students' academic achievement. Procedia - Social and Behavioral Sciences, 29, 836-845. DOI: https:// doi.org/10.1016/j.sbspro.2011.11.31 2.

Iorga, M., Ciuhodaru, T., \& Romedea, S.-N. (2013). Ethic and unethic. Students and the unethical behavior during academic years. Procedia - Social and Behavioral Sciences, 93(21 October), 54-58. DOI: https:// doi.org/10.1016/j.sbspro.2013 .09.151.

Izzah, L. (2019). Menumbuhkan nilai-nilai anti korupsi pada anak untuk membentuk karakter melalui " semai games "di MDTA rabithatul ulum Pekanbaru. PSYCHOPOLYTAN (Jurnal Psikologi), 2(2), 84-95. Retrieved from file:///C:/Users/LENOVO/Downloads/748 -Article\%20Text-1955-1-10-20190710.pdf.

Jose, O. (2013). Stages of Moral reasoning among university students in Papua New Guinea. Journal of Human Values, 19(1), 55-64. DOI: https://doi.org/10.1177/0971685812470333.

Koul, R. (2012). Multiple motivational goals, values, and willingness to cheat. International Journal of Educational Research, 56, 1-9. DOI: https://doi.org/10.1016/j.ijer.2012.10.002.

Langa, C. (2013). Investigation of students' attitude to academic honesty-empiri- cal study. Procedia - Social and Behavioral Sciences, 76(15 April), 426-430. DOI: https://doi.org/10.1016/j.sbspro.2013 .04 .140 .

Lawson, R.A. (2004). Is classroom cheating related to business students' propensity to cheat in the "real world"? Journal of Business Ethics, 49(2), 189-199. DOI:https://doi.org/10.1023/B:BUSI.0000015784.34148.cb.

Djou, A.M.G. \& Quintarti, M.A.L., (2018). Women's Participation in political parties and simultaneous elections. Law Research Review Quarterly, 4(3), 601-610. DOI: https://doi.org/10.15294/snh.v4i03.27052.

Mudaris, H. (2009). Diskursus kesetaraan gender dalam perspektif hukum Islam: Menuju relasi laki-laki dan perempuan yang adil dan setara. Yinyang: Jurnal Studi Islam, Gender, dan Anak, 4(2), 234248. Retrieved from http://ejournal.iainpurwokerto.ac.id/index.php/yiny ang/article/view/231/201.

Murdock, T.B., \& Stephens, J.M. (2007). Is cheating wrong? Students' reasoning about academic dishonesty. In E. M. Anderman \& T.B. Murdock (Eds.), Psychology of Academic Cheating (pp. 229251). Burlington: Elsevier. DOI: https:// doi.org/10.1016/B978-0123725417/50014-0.

Palmer, E.J. (2005). The relationship between moral reasoning and aggression, and the implications for practice. Psychology, Crime \& Law, 11(4), 353-361. DOI: https://doi.org/10.1080/10683160500255190.

Patall, E.A., \& Leach, J.K. (2015). The role of choice provision in academic disho- 
nesty. Contemporary Educational Psychology, 42, 97-110. DOI: https://doi.org/10.1016/j.cedpsych.2015.06.004.

Prantiasih, A. (2014). Reposisi peran dan fungsi perempuan. Jurnal Pendidikan Pancasila Dan Kewarganegaraan, 27(1), 1-6. Retrieved from arbaiyah.prantiasih.fis@um.ac.id.

Schwieren, C., \& Weichselbaumer, D. (2010). Does competition enhance performance or cheating? A laboratory experiment. Journal of Economic Psychology, 31(3), 241-253. DOI: https:// doi.org/10.1016/j.joep.2009.02.005.

Stephens, J.M. (2007). Is cheating wrong? Students' reasoning about academic dishonesty. Psychology of Academic Cheating, 229-251. DOI: https://doi.org/10.1016/B978-0123725417/50014-0.

Strauss, M.E., \& Smith, G.T. (2009). Construct validity: Advances in theory and methodology. Annual Review of Clinical Psychology, 5(1), 1-25. DOI: https://doi.org/10.1146/annurev.clinpsy.0324 08.153639 .

Sudarsana, I.K. (2018). Ajaran Satya dan dharma dalam membentuk karakter keluarga Hindu di Desa Peguyangan Kangin Kota Denpasar. Jurnal Sains Dan Sosial Humaniora, 2(2), 289-302. DOI: $10.30595 /$ jssh.v2i2.2188.

Sykes, G.M., \& Matza, D. (1957). Techniques of neutralization: A theory of delinquency. American Sociological Review, 22(6), 664. DOI: https://doi.org/10.$2307 / 2089195$.
Tan, B.P., Naidu, N.B.M., \& Osman, Z.J. (2018). Moral values and good citizens in a multi-ethnic society: A content analysis of moral education textbooks in Malaysia. Journal of Social Studies Research, 42(2), 119-134. DOI: https://doi.org/10.1016/j.jssr.2017.05.004.

Turiel, E. (2015). Moral reasoning in psychology. In International Encyclopedia of the Social \& Behavioral Sciences (pp. 803805). Elsevier. DOI: https://doi.org/10.1016/B978-0-08-097086-8.25020-4.

Ward, D.A., \& Beck, W.L. (1990). Gender and dishonesty. Journal of Social Psychology, 130(3), 333-339. DOI: https://doi.org/10.1080/00224545.1990.99245 89.

Whitley, B. E. (2001). Gender differences in affective responses to having cheated: The mediating role of attitudes. Ethics and Behavior, 11(3), 249-259. DOI: https://doi.org/10.1207/S15327019EB 1103_4.

Yaniv, G., Siniver, E., \& Tobol, Y. (2017). Do higher achievers cheat less? An experiment of self-revealing individual cheating. Journal of Behavioral and Experimental Economics, 68, 91-96. DOI: https://doi.org/10.1016/j.socec.2017. 04.005 . 